\title{
ANALISIS METODE PENGEMBANGAN SISTEM INFORMASI BERBASIS WEBSITE: A LITERATUR REVIEW
}

\author{
Yudin Wahyudin ${ }^{*}$, Dhian Nur Rahayu ${ }^{2}$ \\ ${ }^{1}$ Yudin Wahyudin: ${ }^{1}$ STMIK Rosma \\ ${ }^{2}$ Dhian Nur Rahayu: ${ }^{2}$ STMIK Rosma \\ Email: yudin@rosma.ac.id, dhian.rahayu@dosen.rosma.ac.id
}

\begin{abstract}
Currently the development of information technology is very fast. Information technology is needed in human life. One of the functions of information system technology is to help or encourage human work to run more effectively and efficiently. Information system development has many methods and various platforms. Platforms that can be used in the development of information systems are mobile, web or desktop based platforms. This study aims to determine a website-based information system development model, and the data is obtained through relevant literature from 2016 to 2020. The method used in this study is the System Literature Review (SLR). The SLR method is used to identify, review, evaluate and interpret all available research in the subject area of the phenomenon of interest, as well as specific related research questions. Using the SLR method, journal articles can be systematically reviewed and identified, and predetermined steps or procedures can be followed in each process. The results of this study indicate that the main method used in the development of website-based information systems, and the advantages and disadvantages of developing website-based information systems used in this study.
\end{abstract}

Keywords: Information System Development, Systematic Literatur Review (SLR), Website

Abstrak

Saat ini perkembangan teknologi informasi sangat pesat. Teknologi informasi sangat dibutuhkan dalam kehidupan manusia. Salah satu fungsi teknologi sistem informasi adalah membantu atau mendorong pekerjaan manusia agar berjalan lebih efektif dan efisien. Pengembangan sistem informasi memiliki banyak metode dan platform yang beragam. Platform yang dapat digunakan dalam pengembangan sistem informasi adalah platform berbasis mobile, web atau desktop. Penelitian ini bertujuan untuk menentukan model pengembangan sistem informasi berbasis website, dan datanya diperoleh melalui literatur yang relevan dari tahun 2016 hingga 2020. Metode yang digunakan dalam penelitian ini adalah System Literature Review (SLR). Metode SLR digunakan untuk mengidentifikasi, meninjau, mengevaluasi, dan menafsirkan semua penelitian yang tersedia di bidang subjek dari fenomena yang menarik, serta pertanyaan penelitian terkait tertentu. Dengan menggunakan metode SLR, artikel jurnal dapat direview dan diidentifikasi secara sistematis, dan langkah atau prosedur yang telah ditentukan dapat diikuti dalam setiap proses. Hasil penelitian ini menunjukkan bahwa metode utama yang digunakan dalam pengembangan sistem informasi berbasis website, dan kelebihan dan kekurangan pengembangan sistem informasi berbasis website yang digunakan dalam penelitian ini.

Kata Kunci: Pengembangan Sistem Informasi, Systematic Literatur Review (SLR), Website,

Jurnal Interkom: Jurnal Publikasi Ilmiah Bidang Teknologi Informasi dan Komunikasi

Volume 15 Nomor 03 Bulan Oktober - Tahun 2020 


\section{Article History:}

Accepted 3, November,2020

\section{Corresponding Author:}

Nama Penulis, Yudin Wahyudin

Departemen, STMIK Rosma

Instansi, STMIK Rosma

Alamat, Jl. Kertabumi No.62 Karawang Barat 41311 Karawang, Jawa Barat.

Email Penulis, yudin@rosma.ac.id

\section{Pendahuluan}

Sistem informasi mempunyai peranan yang sangat penting, semakin pesat perkembangan suatu perusahaan atau organisasi maka sistem informasinya juga mempunyai peranan yang semakin penting. Tuntutan keberadaan sistem informasi yang semakin baik adalah akibat adanya tuntutan perkembangan perusahaan, perkembangan teknologi, kebijakan pemerintah, perubahan prosedur serta tuntutan kebutuhan informasi. Pengembangan sistem Informasi sering disebut sebagai proses pengembangan sistem (system development). Pengembangan sistem informasi didefinisikan sebagai aktivitas untuk menghasilkan sistem informasi bebrbasis komputer untuk menyelesaikan persoalan organisasi atau memanfaatkan kesempatan (oppurtinities) yang timbul. Pengembangan sistem dapat berarti menyusun sistem yang baru untuk menggantikan sistem lama secara keseluruan atau memperbaiki sistem yang telah ada, hal itu dilakukan karena sistem sebelumnya memiliki masalah, tidak efisiennya operasi, dan lain sebagainya.

Pengembangan sistem informasi tidak lepas dengan System Development Life Cycle atau yang lebih dikenal dengan istilah SDLC adalah metodologi umum yang digunakan untuk mengembangkan sistem informasi. SDLC terdiri dari beberapa fase yang dimulai dari fase perencanaan, analisis, perancangan, implementasi hingga pemeliharaan sistem. Konsep SDLC ini mendasari berbagai jenis model pengembangan perangkat lunak untuk membentuk suatu kerangka kerja untuk perencanaan dan pengendalian pembuatan sistem informasi. SDLC adalah proses mengembangkan atau mengubah suatu sistem perangkat lunak dengan menggunakan model-model dan metodologi yang digunakan orang untuk mengembangkan sistem-sistem perangkat lunak sebelumya (berdasarkan best practice atau cara-cara yang sudah teruji baik). SDLC memiliki beberapa Model dalam penerapan tahapan prosesnya antara lain model Sequential Model atau Waterfall, Parallel Model, Iterative Model, Prototyping Model, RAD (Rapid Application Development) Model, Spiral Model, VShaped Model dan Agile Development.

Sistem informasi berbasis web merupakan sebuah sarana didalam sistem komputerisasi yang telah dilengkapi dengan fitur-fitur dan didesain sedemikian rupa sesuai dengan kebutuhan yang akan digunakan pada penginputan suatu data tertentu yang bertujuan untuk mempermudah, mempercepat dan mengakuratkan data yang telah diolah. Website merupakan kumpulan komponen yang terdiri dari teks, gambar, suara animasi sehingga merupakan media informasi yang 
menarik dan sangat dimininati untuk dipergunakan sebagai media berbagi informasi. Teknologi website mengolah data menjadi sebuah informasi dengan cara mengidentifikasi, mengumpulkan, mengelola dan menyediakan untuk dapat diakses secara bersama-sama. Mengingat pentingnya metode pengembangan sistem informasi, maka pada penelitian ini dikumpulkan data-data dari penelitian terdahulu tentang sistem informasi untuk mengetahui metode pengembangan sistem informasi berbasis website.

Penelitian yang akan dilakukan menggunakan metode tinjauan literatur secara sistematis yang merupakan cara untuk mengevaluasi dan menginterpretasikan semua penelitian yang tersedia berdasarkan pertanyaan penelitian khusus, area topik atau fenomena. Kajian literatur ini diharapkan bisa memberikan tinjauan tentang metodemetode pengembangan sistem informasi berbasis website yang sering muncul pada artikel-artikel yang terdapat dalam database jurnal mulai dari tahun 2016 sampai tahun 2020.

\section{Tinjauan Pustaka}

\subsection{Systematic Literatur Review (SLR)}

Systematic Review merupakan istilah yang digunakan untuk merujuk pada metodologi penelitian atau riset tertentu, pengembangan yang dilakukan untuk mengumpulkan dan mengevaluasi penelitian yang terkait pada fokus topik tertentu. Beberapa peneliti yang telah melakukan riset dengan SLR, mendefinisikan SLR sebagai berikut [1]:

a. SLR merupakan cara untuk mengidentifikasi, mengevaluasi dan menafsirkan semua penelitian yang tersedia dengan pertanyaan penelitian tertentu, atau bidang topik, atau fenomena yang menarik.

b. SLR adalah pendekatan evidence-based untuk mencari studi yang relevan dengan beberapa pertanyaan penelitian yang telah ditetapkan dengan memilih, menilai, dan mensintesis temuan untuk menjawab pertanyaan penelitian.

c. SLR suatu teknik penelitian untuk menganalisis state of-the-art dalam bidang pengetahuan tertentu dengan secara resmi mendefinisikan pernyataan masalah, sumber-sumber informasi, string search, kriteria inklusi dan eksklusi dari makalah yang ditemukan dalam). pencarian, analisis kuantitatif yang akan dilakukan (jika perlu), dan template untuk menemukan informasi yang dikumpulkan dari kertas atau papers.

d. SLR merupakan suatu teknik penelitian yang digunakan untuk mengkaji atau menemukan isu-isu yang terdapat dalam Software Engineering.

\subsection{Pengembangan Sistem Informasi}

Pengembangan sistem informasi sering disebut dengan proses pengembangan sistem (system development). Pengembangan sistem dapat didefinisikan sebagai menyusun suatu sistem yang baru untuk menggantikan sistem yang lama secara keseluruhan atau memperbaiki sistem yang telah ada [2]. Banyak metode pengembangan sistem yang tersedia. Metode yang paling dikenal disebut juga sebagai System Development Life Cycle (SDLC). SDLC memiliki beberapa Model dalam penerapan tahapan prosesnya antara lain model Sequential Model atau Waterfall, Parallel Model, Iterative Model, Prototyping Model, RAD (Rapid Application Development) Model, Spiral Model, VShaped Model dan Agile Development. Jadi, pengembangan sistem yaitu suatu sistem yang lama diolah sedemikian rupa atau diganti agar menjadi suatu sistem baru dan mengalami perubahan kearah yang lebih baik dan lebih berguna. Sistem yang lama perlu diperbaiki atau diganti disebabkan karena beberapa hal yaitu adanya permasalahan, untuk meraih kesempatan- kesempatan yang baru dan bila adanya instruksi-instruksi dari pimpinan.

\subsection{Website}

Jurnal Interkom: Jurnal Publikasi Ilmiah Bidang Teknologi Informasi dan Komunikasi

Volume 15 Nomor 03 Bulan Oktober - Tahun 2020 
Website merupakan sebuah kumpulan halaman-halaman web beserta file-file pendukungnya, seperti file gambar, video, dan file digital lainnya yang disimpan pada sebuah web server yang umumnya dapat diakses melalui internet. Atau dengan kata lain, website adalah sekumpulan folder dan file yang mengandung banyak perintah dan fungsi-fungsi tertentu, seperti fungsi tampilan, fungsi menangani penyimpanan data, dsb [3]. Menurut Arief (2011) dalam [4] website adalah kumpulan dari halaman web yang sudah dipublikasikan di jaringan internetdan memiliki domain/URL (Uniform Resource Locator) yang dapat diakses semua pengguna internet dengan cara mengetikan alamatnya. Hal ini dimungkinkan dengan adanya teknologi World Wide Web (WWW). Halaman website biasanya berupa dokumen yang ditulis dalam format Hyper Text Markup Language (HTML), yang bisa diakses melalui HTTP, HTTPS adalah suatu protokol yang menyampaikan berbagai informasi dari server website untuk ditampilkan kepada para user atau pemakai melalui web browser.

\section{Metode}

\subsection{Research Question}

Pertanyaan penelitian dibuat berdasarkan kebutuhan dari topik yang dipilih. Berikut ini adalah pertanyaan penelitian yang digunakan dalam penelitian ini:

RQ1: Apa metode pengembangan sistem informasi berbasis website yang paling sering digunakan pada tahun 2016-2020?

RQ2: Apa kelebihan dan kelemahan pengembangan sistem infomasi berbasis website berdasarkan metode-metode yang telah didapatkan?

RQ3: Bagaimana proses pengembangan sistem informasi berbasis website menggunakan Website Development Life Cycle (WDLC)?

\subsection{Search Process}

Search Process digunakan untuk mendapatkan atau mencari sumber-sumber yang relevan untuk menjawab Research Question (RQ), dan referensi terkait lainnya dengan menggunakan search engine (Mozilla firefox) dengan alamat situs https://scholar.google.com. dan http://garuda.ristekdikti.go.id.

Dalam melakukan SLR, dibutuhkan strategi dan metode dalam pencarian penelitian terhadap penelitian yang terkait. Tahap pertama ialah pencarian penelitian yang terkait berdasarkan kata kunci pencarian. Kata kunci untuk mencari literatur dalam penelitian ini adalah "Metode Pengembangan Sistem Informasi" \& "Pengembangan Sistem Informasi berbasis website" dan "Pengembangan Sistem Informasi" \& "Aplikasi Berbasis Website". Kata kunci ini kemudian dimasukkan kedalam fitur pencarian yang tersedia di Google Scholar dan Garuda. Serta pilih pilihan tahun. Tahap kedua ialah Review 1 dimana mengidentifikasi dan menganalisa melalui luaran literatur. Pada tahap ini, paper penelitian yang didapatkan pada pencarian paper akan diseleksi. Penyeleksian paper diantaranya: (1) Eliminasi literatur dengan judul yang tidak sesuai dengan kata kunci yang telah ditentukan. (2) Eliminasi literatur yang bukan konferensi atau jurnal. (3) Eliminasi paper yang duplikat. (4) Eliminasi literatur yang tidak sesuai dengan rentang tahun yang sudah ditentukan. Hasil dari Review 1 akan dibawa pada Review 2 dimana menganalisa melalui dalaman paper. Pada tahap Review 2, dilakukan analisa dari sisi abstrak. Literatur yang tersisa akan diseleksi dengan cara: (1) Eliminasi literatur dengan abstrak yang tidak terkait dengan kata kunci yang telah ditentukan. (2) Eliminasi literatur dengan metodologi penelitian yang tidak termasuk dalam pengembangan sistem berbasis website. (3) Eliminasi paper dengan konten atau format paper yang tidak umum. Hasil yang tersisa pada Review 2 ini akan dikelompokan berdasarkan metode

Jurnal Interkom: Jurnal Publikasi Ilmiah Bidang Teknologi Informasi dan Komunikasi

Volume 15 Nomor 03 Bulan Oktober - Tahun 2020 
pengembangan sistem informasi yang digunakan. Kemudian pada tahap terakhir, peneliti melakukan penyeleksian. Penyeleksian yang dilakukan ialah seleksi dengan menilai kualitas paper berdasarkan daftar dari Quality Assessment (QA).

\subsection{Quality Assesment}

Quality Assessment atau QA dibentuk berdasarkan dari daftar rumusan masalah. QA harus bersis penilaian untuk menjawab semua rumusan masalah. Dalam penelitian ini, data yang ditemukan akan dievaluasi berdasarkan pertanyaan kriteria penilaian kualitas sebagai berikut:

QA1: Apakah literatur tersebut ditebitkan pada tahun 2016-2020?

QA2: Apakah pada literatur tersebut menuliskan platform yang digunakan dalam penelitian tersebut?

QA3: Apakah pada literatur tersebut memberikan informasi metode yang digunakan untuk mengembangkan sistem informasi tersebut?

Dari masing-masing literatur, akan diberi nilai jawaban di bawah ini untuk tiaptiap pertanyaan di atas.

Y (Ya): untuk literatur yang sesuai dengan pertanyaan pada quality assessment.

$\mathrm{T}$ (Tidak): untuk literatur yang tidak sesuai dengan pertanyaan pada quality assessment.

\section{Hasil dan Pembahasan}

Penelitian Systematic Literature Review (SLR) untuk mengetahui metode-metode yang digunakan dalam pengembangan sistem informasi berbasis website. Data yang digunakan dalam penelitian ini adalah dalam rentang waktu 2016-2020 untuk menjaga kemutakhiran dan keterbaruan literatur yang akan diulas. Data diperoleh melalui situs https://scholar.google.com dan http://garuda.ristekdikti.go.id. Data yang digunakan hanya berhubungan dengan metode pengembangan sistem informasi berbasis website. Hasil dari pencarian literatur yang dilakukan pada Google
Scholar dan Garuda adalah sebanyak 302 literatur kemudian paper didapatkan dari proses pencarian akan diseleksi. Tahap pertama yaitu review 1 peneliti melakukan penyeleksian paper jurnal berdasarkan judul, Namun, dari 302 literatur hanya 183 literatur yang judulnya memiliki relevansi dengan kata kunci yang telah ditetapkan sebelumnya, karena kebanyakan literatur tidak berfokus pada metode pengembangan sistem informasi berbasis website. Pada tahap kedua, peneliti melakukan penyeleksian berdasarkan abstrak, hasil penyeleksian ini dari 183 literatur hanya terdapat 108 paper yang memiliki kesesuaian dengan kata kunci yang sudah ditentukan. Pada tahap berikutnya peneliti melakukan pengelompokan paper jurnal berdasarkan metode pengembangan sistem informasi, hasilnya terdapat 33 litreratur menggunakan metode waterfall, 1 literatur menggunakan metode R\&D, 6 literatur menggunakan metode RAD, 6 literatur menggunakan RUP, 5 literatur menggunakan metode prototype, dan 1 literatur menggunakan WDLC dan 48 literatur tidak menyebutkan metode pengembangannya. Selanjutnya pada tahap akhir, peneliti melakukan penilaian quality assessment, hasilnya dari 108 literatur peneliti mendapatkan 52 literatur yang memenuhi syarat. Hasil dari 52 literatur tersebut yang akan dijadikan referensi oleh peneliti untuk melakukan systematic literature review. 


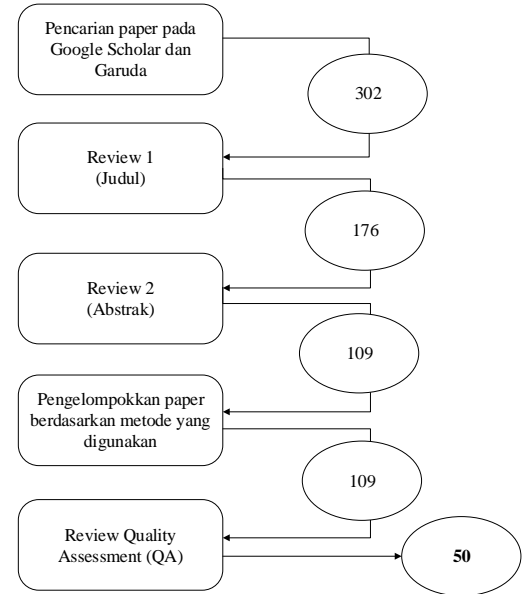

Gambar 1 Literatur yang dihasilkan dari Setiap Proses

Hasil dari penilaian Quality Assesment pada literatur yang telah dipilih yang dapat digunakan sebagai rujukan untuk menjawab RQ1 dapat dilihat pada tabel 1.

Tabel 1 Hasil Quality Assessment

\begin{tabular}{|c|c|c|c|c|c|c|}
\hline No. & Literatur & Tahun & Q1 & Q2 & Q3 & Hasil \\
\hline 1. & {$[5]$} & 2017 & Y & Y & Y & $\checkmark$ \\
\hline 2. & {$[6]$} & 2019 & Y & Y & Y & $\checkmark$ \\
\hline 3. & {$[7]$} & 2017 & Y & Y & Y & $\checkmark$ \\
\hline 4. & {$[8]$} & 2017 & Y & Y & Y & $\checkmark$ \\
\hline 5. & {$[9]$} & 2020 & Y & Y & Y & $\checkmark$ \\
\hline 6. & {$[10]$} & 2018 & Y & Y & Y & $\checkmark$ \\
\hline 7. & {$[11]$} & 2018 & Y & Y & Y & $\checkmark$ \\
\hline 8. & {$[12]$} & 2017 & Y & Y & Y & $\checkmark$ \\
\hline 9. & {$[13]$} & 2019 & Y & Y & Y & $\checkmark$ \\
\hline 10. & {$[14]$} & 2016 & Y & Y & Y & $\checkmark$ \\
\hline 11. & {$[15]$} & 2016 & Y & Y & Y & $\checkmark$ \\
\hline 12. & {$[16]$} & 2019 & Y & Y & Y & $\checkmark$ \\
\hline 13. & {$[17]$} & 2017 & Y & Y & Y & $\checkmark$ \\
\hline 14. & {$[18]$} & 2018 & Y & Y & Y & $\checkmark$ \\
\hline 15. & {$[19]$} & 2017 & Y & Y & Y & $\checkmark$ \\
\hline 16. & {$[20]$} & 2020 & Y & Y & Y & $\checkmark$ \\
\hline 17. & {$[21]$} & 2019 & Y & Y & Y & $\checkmark$ \\
\hline 18. & {$[22]$} & 2020 & Y & Y & Y & $\checkmark$ \\
\hline 19. & {$[23]$} & 2018 & Y & Y & Y & $\checkmark$ \\
\hline 20. & {$[24]$} & 2018 & Y & Y & Y & $\checkmark$ \\
\hline 21. & {$[25]$} & 2019 & Y & Y & Y & $\checkmark$ \\
\hline 22. & {$[26]$} & 2017 & Y & Y & Y & $\checkmark$ \\
\hline 23. & {$[27]$} & 2016 & Y & Y & Y & $\checkmark$ \\
\hline 24. & {$[28]$} & 2017 & Y & Y & Y & $\checkmark$ \\
\hline 25. & {$[29]$} & 2019 & Y & Y & Y & $\checkmark$ \\
\hline 26. & {$[30]$} & 2020 & Y & Y & Y & $\checkmark$ \\
\hline 27. & {$[31]$} & 2016 & Y & Y & Y & $\checkmark$ \\
\hline 28. & {$[32]$} & 2017 & Y & Y & Y & $\checkmark$ \\
\hline 29. & {$[33]$} & 2016 & Y & Y & Y & $\checkmark$ \\
\hline 30. & {$[34]$} & 2017 & Y & Y & Y & $\checkmark$ \\
\hline 31. & {$[35]$} & 2020 & Y & Y & Y & $\checkmark$ \\
\hline
\end{tabular}

\begin{tabular}{|c|c|c|c|c|c|c|}
\hline No. & Literatur & Tahun & Q1 & Q2 & Q3 & Hasil \\
\hline 32. & {$[36]$} & 2019 & Y & Y & Y & $\checkmark$ \\
\hline 33. & {$[37]$} & 2020 & Y & Y & Y & $\checkmark$ \\
\hline 34. & {$[38]$} & 2019 & Y & Y & Y & $\checkmark$ \\
\hline 35. & {$[39]$} & 2020 & Y & Y & Y & $\checkmark$ \\
\hline 36. & {$[40]$} & 2016 & Y & Y & Y & $\checkmark$ \\
\hline 37. & {$[41]$} & 2019 & Y & Y & Y & $\checkmark$ \\
\hline 38. & {$[42]$} & 2019 & Y & Y & Y & $\checkmark$ \\
\hline 39. & {$[43]$} & 2019 & Y & Y & Y & $\checkmark$ \\
\hline 40. & {$[44]$} & 2017 & Y & Y & Y & $\checkmark$ \\
\hline 41. & {$[45]$} & 2017 & Y & Y & Y & $\checkmark$ \\
\hline 42. & {$[46]$} & 2019 & Y & Y & Y & $\checkmark$ \\
\hline 43. & {$[47]$} & 2020 & Y & Y & Y & $\checkmark$ \\
\hline 44. & {$[48]$} & 2016 & Y & Y & Y & $\checkmark$ \\
\hline 45. & {$[2]$} & 2016 & Y & Y & Y & $\checkmark$ \\
\hline 46. & {$[49]$} & 2017 & Y & Y & Y & $\checkmark$ \\
\hline 47. & {$[50]$} & 2019 & Y & Y & Y & $\checkmark$ \\
\hline 48. & {$[51]$} & 2020 & Y & Y & Y & $\checkmark$ \\
\hline 49. & {$[52]$} & 2018 & Y & Y & Y & $\checkmark$ \\
\hline 50. & {$[53]$} & 2018 & Y & Y & Y & $\checkmark$ \\
\hline
\end{tabular}

Keterangan Simbol:

$\checkmark$ : Untuk literatur atau data yang digunakan penelitian.

$x$ : $\quad$ Untuk literatur atau data yang tidak digunakan dalam penelitian.

RQ1. Apa metode pengembangan sistem informasi berbasis website yang paling sering digunakan pada tahun 2016-2020?

Tabel 2 menampilkan hasil pengelompokan metode yang menjawab RQ1.

Tabel 2 Metode Pengembangan Sistem Informasi

\begin{tabular}{|c|l|c|}
\hline No. & $\begin{array}{l}\text { Motode Pengembangan } \\
\text { Sistem Informasi }\end{array}$ & Total \\
\hline 1. & Metode Waterfall & 31 \\
\hline 2. & $\begin{array}{l}\text { Metode Rapid Application } \\
\text { Development (RAD) }\end{array}$ & 6 \\
\hline 3. & $\begin{array}{l}\text { Metode Rational Unified } \\
\text { Process (RUP) }\end{array}$ & 6 \\
\hline 4. & \begin{tabular}{l} 
Metode Prototype \\
\hline 5.
\end{tabular} & $\begin{array}{l}\text { Metode Research and } \\
\text { Development (R\&D) }\end{array}$ \\
\hline 6. & $\begin{array}{l}\text { Metode Web Development } \\
\text { Life Cycle (WDLC) }\end{array}$ & 1 \\
\hline
\end{tabular}

Berdasarkan tabel 2 metode yang paling sering digunakan dalam pengembangan sistem informasi (2016-2020) adalah waterfall. 
Waterfall merupakan salah satu Software Development Life Cycle (SDLC) dimana aktivitas pengembangan perangkat lunak dimulai dari spesification, development, validation, dan evolution lalu membaginya menjadi fase proses seperti spesifikasi kebutuhan, rancangan perangkat lunak, implementasi, pengujian, dan lainlain. Kelebihan model Waterfall adalah mudah dipahami, milestone dipahami dengan baik, requirement akan menjadi stabil, dan menyediakan struktur untuk staff yang tidak berpengalaman [21]. Model Waterfall memiliki lima tahap sesuai dengan Gambar 2.

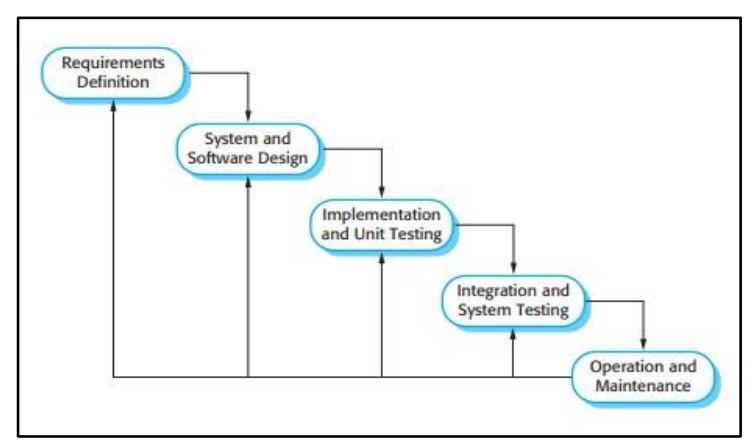

Gambar 2 Tahapan Model Waterfall

1. Requirement analysis dan definition, merupakan proses analisis kebutuhan pengguna untuk mengetahui tujuan, batasan serta layanan pada suatu sistem. Dalam tahap ini kebutuhan didefinisikan secara detail dan digunakan sebagai spesifikasi sistem,

2. System dan software design, merupakan proses perancangan sistem berdasarkan kebutuhan dengan membangun keseluruhan arsitektur sistem. Perancangan perangkat lunak melibatkan kegiatan identifikasi dan mendeskripsikan abstraksi sistem perangkat lunak dan hubungannya,

3. Implementation dan unit testing, dalam tahap ini rancangan perangkat lunak diimplementasikan sebagai unit program lalu diuji menggunakan strategi pengujian unit,
4. Integration dan sistem testing, dalam tahap ini unit program diintegrasikan satu sama lain agar fungsi dapat berjalan lalu diuji menggunakan strategi pengujian integrasi,

5. Operation dan maintenance, dalam tahap ini sistem dirawat jika ditemukan error, atau meningkatkan unit implementasi serta meningkatkan layanan sistem.

\section{RQ2. Apa kelebihan dan kelemahan pengembangan sistem infomasi berbasis website berdasarkan metode-metode yang telah didapatkan?}

Kelebihan dan kekurangan metode pengembangan sistem informasi untuk menjawab RQ2 dapat dilihat pada tabel 2.

Tabel 3 Kelebihan dan Kekurangan Metode Pengembangan Sistem Informasi

\begin{tabular}{|l|l|l|}
\hline \multicolumn{1}{|c|}{ Metode } & \multicolumn{1}{|c|}{ Kelebihan } & \multicolumn{1}{c|}{ Kekurangan } \\
\hline Metode & 1) Mudah dalam & 1) Tahapan yang \\
pengelolaan & berurutan secara \\
& karena hampir & linier tidak \\
seluruh & memungkinkan \\
& requirements & untuk kembali \\
telah & pada tahapan \\
diidentifikasikan & selanjutnya, 2) \\
& dan & Tidak fleksibel \\
& didokumentasikan & terhadap \\
& 2) Tahapan yang & perubahan \\
& berurutan secara & kebutuhan yang \\
& linier, identifikasi & terjadi dalam \\
dan dokumentasi & tahap \\
& yang lengkap, & pengembangan \\
& menyebabkan & sistem, 3) Hampir \\
& proses mudah & tidak ada toleransi \\
dipahami oleh & kesalahan, \\
& seluruh tim yang & terutama pada \\
& terlibat ataupun & tahapan planning \\
& project owner & dan design [54]. \\
& [54]. & \\
\hline Metode Rapid & 1) Lebih efektif & 1) Model RAD \\
Application & dari & menuntut \\
Development & Pengembangan & pengembangan \\
(RAD) & Model waterfall & dan pelanggan \\
& sequentia linear & memiliki \\
dalam & komitmen di \\
& menghasilkan & dalam aktivitas \\
& sistem yang & rapid-fire yang \\
memenuhi & diperlukan untuk \\
kebutuhan & melengkapi \\
& langsung dari & sebuah sistem, di \\
pelanggan. 2) & dalam kerangka \\
\hline
\end{tabular}




\begin{tabular}{|c|c|c|c|c|c|}
\hline Metode & \multirow{3}{*}{\begin{tabular}{l}
\multicolumn{1}{c}{ Kelebihan } \\
Cocok untuk \\
proyek yang \\
memerlukan \\
waktu yang \\
singkat. 3) Model \\
RAD mengikuti \\
tahap \\
pengembangan \\
sistem seperti \\
pada umumnya, \\
tetapi mempunyai \\
kemampuan \\
untuk \\
menggunakan \\
kembali \\
komponen yang \\
ada sehingga \\
pengembang tidak \\
perlu \\
membuatnya dari \\
awal lagi \\
sehingga waktu \\
pengembangan \\
menjadi lebih \\
singkat dan \\
efisien [55].
\end{tabular}} & Kekurangan & \multirow[t]{2}{*}{ Metode } & \multirow[b]{2}{*}{\begin{tabular}{l}
\multicolumn{1}{c}{ Kelebihan } \\
untuk secara \\
sistematis \\
mengontrol \\
perubahan- \\
perubahan yang \\
terjadi pada \\
software selama \\
proses \\
pengembanganny \\
a. 6) \\
Memungkinkan \\
untuk \\
menjalankan test \\
[56].
\end{tabular}} & \multirow[t]{2}{*}{ Kekurangan } \\
\hline & & $\begin{array}{l}\text { waktu yang sangat } \\
\text { diperpendek. Jika } \\
\text { komitmen } \\
\text { tersebut tidak ada, } \\
\text { proyek RAD akan } \\
\text { gagal. 2) Tidak } \\
\text { semua aplikasi } \\
\text { sesuai untuk } \\
\text { RAD, bila system } \\
\text { tidak dapat } \\
\text { dimodulkan } \\
\text { dengan teratur, } \\
\text { pembangunan } \\
\text { komponen }\end{array}$ & & & \\
\hline & & $\begin{array}{l}\text { penting pada } \\
\text { RAD akan } \\
\text { menjadi sangat } \\
\text { bermasalah. 3) } \\
\text { RAD tidak cocok } \\
\text { digunakan untuk } \\
\text { sistem yang } \\
\text { mempunyai resiko } \\
\text { teknik yang } \\
\text { tinggi. 4) } \\
\text { Membutuhkan } \\
\text { Tenaga kerja yang } \\
\text { banyak untuk } \\
\text { menyelesaikan } \\
\text { sebuah proyek } \\
\text { dalam skala besar. } \\
\text { 5) Jika ada } \\
\text { perubahan di } \\
\text { tengah-tengah } \\
\text { pengerjaan maka } \\
\text { harus membuat } \\
\text { kontrak baru } \\
\text { antara } \\
\text { pengembang dan } \\
\text { pelanggan [55]. }\end{array}$ & $\begin{array}{l}\text { Metode } \\
\text { Prototype }\end{array}$ & $\begin{array}{l}\text { 1) Requirements } \\
\text { identification } \\
\text { yang akurat } \\
\text { karena dilakukan } \\
\text { evaluasi secara } \\
\text { berkala dan } \\
\text { mendapatkan } \\
\text { masukan dari } \\
\text { project owner } \\
\text { terhadap purwa } \\
\text { rupa yang } \\
\text { dihasilkan, 2) } \\
\text { User experience } \\
\text { yang meningkat, } \\
\text { karena secara } \\
\text { terus menerus } \\
\text { melakukan uji } \\
\text { coba dan evaluasi } \\
\text { terhadap purwa } \\
\text { rupa, 3) } \\
\text { Kesalahan dan } \\
\text { redudansi dapat } \\
\text { diminimalkan } \\
\text { karena proses } \\
\text { identifikasi yang }\end{array}$ & $\begin{array}{l}\text { 1) Setiap evaluasi } \\
\text { dan masukan } \\
\text { terhadap purwa } \\
\text { rupa, maka akan } \\
\text { membutuhkan } \\
\text { penyesuaian } \\
\text { terhadap purwa } \\
\text { rupa tersebut. Dan } \\
\text { setiap } \\
\text { penyesuaian akan } \\
\text { meningkatkan } \\
\text { kompleksitas } \\
\text { sistem yang } \\
\text { dikembangkan, 2) } \\
\text { Memberikan } \\
\text { beban tambahan } \\
\text { kepada } \\
\text { programmer, 3) } \\
\text { Terdapat } \\
\text { kebutuhan biaya } \\
\text { tambahan terkait } \\
\text { dengan } \\
\text { pembuatan purwa } \\
\text { rupadan dapat } \\
\text { dilakukan }\end{array}$ \\
\hline \multirow[t]{2}{*}{$\begin{array}{l}\text { Metode } \\
\text { Rational } \\
\text { Unified } \\
\text { Process } \\
\text { (RUP) }\end{array}$} & \multirow{2}{*}{$\begin{array}{l}\text { 1) Menyediakan } \\
\text { akses yang mudah } \\
\text { terhadap } \\
\text { pengetahuan } \\
\text { dasar bagi } \\
\text { anggota tim. 2) } \\
\text { Menyediakan } \\
\text { petunjuk } \\
\text { bagaimana } \\
\text { menggunakan } \\
\text { uml secara } \\
\text { efektif. 3) } \\
\text { Mendukung } \\
\text { proses } \\
\text { pengulangan } \\
\text { dalam } \\
\text { pengembangan } \\
\text { software. 4) } \\
\text { Memungkinkan } \\
\text { adanya } \\
\text { penambahanpena } \\
\text { mbahan pada } \\
\text { proses. 5) } \\
\text { Memungkinkan }\end{array}$} & \multirow{2}{*}{$\begin{array}{l}\text { Metodologi ini } \\
\text { hanya dapat } \\
\text { digunakan pada } \\
\text { pengembangan } \\
\text { perangkat lunak } \\
\text { yang berorientasi } \\
\text { objek dengan } \\
\text { berfokus pada } \\
\text { UML (Unified } \\
\text { Modeling } \\
\text { Language) [56]. }\end{array}$} & & $\begin{array}{l}\text { baik terhadap } \\
\text { purwa rupa [54]. }\end{array}$ & $\begin{array}{l}\text { penyesuaian versi } \\
\text { purwa rupa sesuai } \\
\text { kebutuhan, hingga } \\
\text { purwa rupa dapat } \\
\text { disetujui oleh } \\
\text { project owner } \\
\text { [54]. }\end{array}$ \\
\hline & & & $\begin{array}{l}\text { Metode } \\
\text { Research and } \\
\text { Development } \\
\text { (R\&D) }\end{array}$ & $\begin{array}{l}\text { 1) Mampu } \\
\text { mengatasi } \\
\text { kebutuhan nyata } \\
\text { yang mendesak. } \\
\text { (real needs in the } \\
\text { here-and-now) } \\
\text { melalui } \\
\text { pengembangan } \\
\text { solusi atau suatu } \\
\text { masalah dengan } \\
\text { menghasilkan } \\
\text { pengetahuan yang } \\
\text { bisa digunakan di } \\
\text { masa mendatang. } \\
\text { 2) Mampu } \\
\text { menghasilkan } \\
\text { suatu produk atau }\end{array}$ & $\begin{array}{l}\text { 1) Proses } \\
\text { penelitian } \\
\text { memerlukan } \\
\text { waktu yang relatif } \\
\text { panjang, karena } \\
\text { prosedur yang } \\
\text { harus di tempuh } \\
\text { lebih rinci dan } \\
\text { teratur. 2) Tidak } \\
\text { bisa } \\
\text { digeneralisasikan } \\
\text { secara utuh } \\
\text { karena penelitian } \\
\text { R\&D di tujukan } \\
\text { untuk pemecahan } \\
\text { masalah dan di } \\
\text { buat berdasarkan }\end{array}$ \\
\hline
\end{tabular}

Jurnal Interkom: Jurnal Publikasi Ilmiah Bidang Teknologi Informasi dan Komunikasi

Volume 15 Nomor 03 Bulan Oktober - Tahun 2020 
Berikutnya dilanjutkan dengan menentukan informasi yang ada di dalam website.

2. Analisa

Analisis diawali dengan mengumpulkan kebutuhan informasi pengguna. Dilanjutkan dengan analisis fungsi aplikasi mencakup input data beserta sumbernya dan output darisistem dengan penyajian datanya. Langkah langkah analisis dalam WDLC adalah sebagai berikut:

a. Identifikasi tugas dari pengguna yang harus diselesaikan. Setelah tugas-tugas pengguna diketahui, analisis fungsi aplikasi dari sitem bisa dilakukan.

b. Mempertimbangkan proses yang dibutuhkan untuk mendukung fitur yang ada didalam website.

c. Menjamin website yang dibuat sesuai dengan kebutuhan pengguna. Karena kesalahan dalam analisis berdampak fatal dalam tahap berikutnya.

3. Perancangan dan Pengembangan

Hasil dari analisis merupakan acuan dalam merancang dan mengembangkan website. Langkah awal dalam tahapan ini adalah dengan mempersiapkan blue print dari website. Selanjutnya dilakukan perancangan model data, model proses dan model tampilan. Setelah itu perancangan sistem didokumentasikan. Hasil dokumentasi digunakan sebagai acuan dalam membuat program dan dasar pengujian program.

4. Pengujian

Pengujian dilakukan untuk menunjukkan bahwa sistem yang dibuat sesuai dengan kebutuhan pengguna. Dalam metode WDLC komponen yang harus diuji mencakup konten, fungsi, usability, dan kebenaran program. Usability menunjukkan seberapa jauh sistem mampu membantu penguna dalam menyelesaikan tugasnya. Dalam tahap pengujian ini juga mencakup pemeriksaan terhadap validasi, flesibelitas, kecepatan, kemudahan akses, dan independensi.

5. Implementasi dan Perawatan

Pada tahap ini dilakukan instalasi situs web pada sistem komputer pengguna. Pada tahap ini pengguna dapat berinteraksi langsung dengan sistem yang telah dibuat.

\section{Penutup}

Berdasarkan hasil penelitian yang telah dilakukan, dapat diambil beberapa kesimpulan sebagai berikut:

1. Mengacu kepada hasil RQ1 yang peneliti lakukan pada literatur jurnal yang dipublikasi dari tahun 2016-2020, metode pengembangan sistem informasi berbasis website yang paling banyak digunakan adalah metode waterfall.

2. Berdasarkan hasil dari RQ2 yang dilakukan pada literatur jurnal, metode pengembangan sistem informasi yang terdiri dari metode waterfall, prototype, RAD, RUP, R\&D dan WDLC menunjukkan fitur kelebihan dan kelemahan masing-masing metode pengembangan.

3. Hasil dari RQ3 yang peneliti lakukan adalah mengetahui metode pengembangan sistem WDLC dengan lima tahapan yaitu, perencanaan, analisa, perancangan dan pengembangan, pengujian, dan implementasi dan perawatan.

\section{Daftar Pustaka}

[1] Lusiana dan Melva Suryani, "Metode SLR untuk Mengidentifikasi Isu-Isu dalam Software Engineering," $J$. SATIN - Sains dan Teknol. Inf., vol. 3, no. 1, hal. 1-11, 2014.

[2] A. D. Hermandra dan Anofrizen, "PENGEMBANGAN SISTEM INFORMASI KERJA PRAKTEK (Studi Kasus: Jurusan Sistem Informasi UIN SUSKA Riau)," $J$. Rekayasa dan Manaj. Sist. Inf., vol. 2, no. 1, hal. 11-14, 2016.

[3] Suhartini, M. Sedali, dan Y. K. Putra, "Sistem Informasi Berbasis Web Sma Al- Mukhtariyah Mamben Lauk Berbasis Php Dan Mysql Dengan 
Framework Codeigniter," vol. 3, no. 1, hal. 79-84, 2020.

[4] Nofyat, A. Ibrahim, dan A. Ambarita, "SISTEM INFORMASI PENGADUAN PELANGGAN AIR BERBASIS WEBSITE PADA PDAM KOTA TERNATE," IJIS-Indonesia J. Inf. Syst., vol. 3, no. 1, hal. 10-19, 2018.

[5] H. N. Ahyudiya dan N. Latifah, "APLIKASI REGISTRASI PEMAKAIAN KIOS PASAR DI PATI BERBASIS WEB PADA DINAS PERDAGANGAN DAN PERINDUSTRIAN KABUPATEN PATI," Pros. SNATIF ke-4 Tahun 2017, hal. 153-160, 2017, doi: 10.2298/PAN0903301G.

[6] S. Arthur, F. Amalia, dan F. A. Bachtiar, "Pengembangan Sistem Informasi Ticketing untuk Pengadaan Barang dengan Algoritme Analytic Hierarchy Process untuk Prioritas berbasis Web (Studi Kasus PT . Kawasaki Motor Indonesia)," $J$. Pengemb. Teknol. Inf. dan Ilmu Komput., vol. 3, no. 11, hal. 1080510812, 2019.

[7] J. Dermawan dan S. Hartini, "IMPLEMENTASI MODEL WATERFALL PADA PENGEMBANGAN SISTEM INFORMASI PERHITUNGAN NILAI MATA PELAJARAN BERBASIS WEB PADA SEKOLAH DASAR AL-AZHAR SYIFA BUDI JATIBENING," vol. 19, no. 2, hal. 142-147, 2017, doi: 10.1093/nq/s5VII.159.37-a.

[8] E. Diana dan As'ad, "Analisis Dan Perancangan Sistem Informasi Tracer Study Berbasis WEB," J. Infomedia, vol. 11, no. 2, hal. 817-829, 2017, doi: 10.30811/jim.v3i2.716.

[9] S. C. Fadilah, H. Rianto, dan T. Hartati, "IMPLEMENTASI FRAMEWORK CODE IGINTER MENGGUNAKAN METODE
WATERFALL PADA SISTEM INFORMASI PENJUALAN PT . SUPREME JAYA ABADI," J. Inf. Syst. Informatics Comput., vol. 4, no. 1, hal. 134-140, 2020.

[10] R. Firliana, F. Rhohman, dan R. W. Purwinanto, "Perancangan Sistem Informasi Absensi Dosen Dengan Validasi Mahasiswa Berbasis Web," J. Sains dan Inform., vol. 4, no. 2, hal. 105, 2018, doi: 10.34128/jsi.v4i2.142.

[11] W. Hamdani dan Suharnawi, "Pengembangan Sistem Informasi Pariwisata Kabupaten Tegal Berbasis Website," J. Inf. Syst., hal. 1-9, 2018.

[12] R. Harisca, A. Huda, dan L. Slamet, "Pengembangan Sistem Informasi Kepegawaian Berbasis Web Pada Man 1 Padang," J. Vokasional Tek. Elektron. dan Inform., vol. 5, no. 2, hal. 148-154, 2017.

[13] M. Jannah, "Perancangan Sistem Informasi Pendaftaran Organisasi Unit Kegiatan Khusus (UKK) Berbasis WEB Di IAIN Bukittinggi," $J$. Inform., vol. 6, no. 2, hal. 185-192, 2019, doi: 10.31311/ji.v6i2.6126.

[14] A. R. Kasmirin, M. Yusman, dan I. Adipribadi, "Perancangan Sistem Informasi Perpustakaan Berbasis Web (Studi kasus SMAN 1 Penengahan)," J. Komputasi, vol. 4, no. 1, hal. 104108, 2016.

[15] K. K. Khotimah, S. Mutrofin, dan Y. Agustiawan, "Pengembangan sistem informasi kuliah pengabdian masyarakat (KPM) di Unipdu Jombang berbasis web," Teknologi, vol. 2, no. 1, hal. 103-111, 2016, doi: 10.26594/teknologi.v6i2.793.

[16] A. P. Kuncoro, B. A. Kusuma, dan A. Purnomo, "Pengembangan Sistem Informasi Berbasis Website Sebagai Media Pengelolaan Peminjaman dan Pengembalian Alat Laboratorium Fikes UMP," SATIN - Sains dan Teknol. Inf., vol. 4, no. 2, hal. 24-30, 2019, doi: 10.33372/stn.v4i2.396. 
[17] T. Kuswantoro, "PENGEMBANGAN SISTEM INFORMASI AKADEMIK PADA AMIK BUMI NUSANTARA BERBASIS WEB," Syntax Lit. J. Ilm. Indones., vol. 2, no. 12, hal. 123-136, 2017.

[18] M. K. Lila Setiyani, ST., "PERANCANGAN SISTEM INFORMASI PENDIDIKAN DAN PELATIHAN (DIKLAT) DI BALAI BESAR PELATIHAN KESEHATAN CILOTO," J. Interkom, vol. 13, no. 1, hal. 18-27, 2018.

[19] E. Maiyana dan T. Mengkasrinal, "Pengembangan Sistem Informasi Surat Keterangan Pendamping Ijazah Berbasis Web dan Mobile Android," Pros. SISFOTEK 2017, hal. 7-16, 2017.

[20] G. Manu dan H. Tugil, "Perancangan Sistem Informasi Manajemen Ekstrakurikuler (Sime) Berbasis Web," J. Pendidik. Teknol. Inf., vol. 3, no. 1, hal. 14-20, 2020, doi: 10.37792/jukanti.v3i1.91.

[21] S. Masyruhatin, Y. T. Mursityo, dan D. Pramono, "Pengembangan Sistem Informasi Penilaian Hasil Belajar Siswa berbasis Web pada SMA Brawijaya Smart School," J. Pengemb. Teknol. Inf. dan Ilmu Komput., vol. 3, no. 10, hal. 9984 9992, 2019.

[22] Muksin, "PERANCANGAN SISTEM INFORMASI AKADEMIK SEKOLAH BERBASIS WEB PADA SMP NEGERI 1 PULAU MOROTAI," IJIS-Indonesia J. Inf. Syst., vol. 5, no. 1, hal. 66-76, 2020, doi: $10.1021 / j p 5128578$.

[23] A. Novryaldy dan T. Seitadi, "Perancangan Sistem Informasi Profil Masjid Berbasis Website," J. Ilm. Teknol. Infomasi Terap., vol. 4, no. 3, hal. 242-252, 2018, doi: 10.33197/jitter.vol4.iss3.2018.172.

[24] N. M. R. A. Permatasari, R. I. Rokhmawati, dan F. Pradana,
"Pengembangan Sistem Informasi Manajemen Reward Pelanggan Berbasis Website pada Pepito Market Cabang Sanur," J. Pengemb. Teknol. Inf. dan Ilmu Komput. Univ. Brawijaya, vol. 2, no. 2, hal. 659-666, 2018.

[25] S. Pratama, "PERANCANGAN SISTEM INFORMASI PERPUSTAKAAN BERBASIS WEB (STUDI KASUS PADA SMP N 1 KERTAK HANYAR)," hal. 327-332, 2019.

[26] H. Purwanto dan S. Dalis, "Perancangan Sistem Informasi Pelayanan Kesehatan Peduli Remaja (Pkpr) Berbasis Web Pada Puskesmas," Semin. Nas. Sains danTeknologi Fak. Tek. Univ. Muhammadiyah Jakarta, vol. 18, no. 218, hal. 1-2, 2017.

[27] Y. Rakhel, A. Hidayat, dan V. G. Utomo, "Perancangan Sistem Informasi Inventaris Berbasis Web Mobile (Studi Kasus : STMIK Provisi Semarang) Yuniati," J. Komputaki, vol. 1, no. 1, hal. 17-25, 2016.

[28] E. Rosiska dan P. R. Nopiana, "Aplikasi Sistem Informasi Akutansi Jasa Penyewaan Kapal Berbasis Web Pada PT.Sekumbang Permata Engineering," J. Akunt., vol. 5, no. 2, hal. 134-144, 2017.

[29] I. Y. Ruhiawati dan S. Sopiah, "Perancangan Sistem Informasi Akademik Sekolah Berbasis Website Dengan Laravel 5 Pada Smk Negeri 1 Cileles," Jurnail Sains dan Teknol., vol. 3, no. 1, hal. 93-106, 2019.

[30] R. Sabaruddin, M. Juniarti, dan W. Nugraha, "Pengembangan Sistem Informasi Perusahaan Konveksi dan Sablon Berbasis Website Menggunakan Metode Waterfall," vol. 01, no. 01, hal. 21-30, 2020.

[31] T. N. Sari, "Analisis Kualitas Dan Pengembangan Sistem Informasi Akademik Berbasis Web 
Menggunakan Standard Iso 9126," JIKO (Jurnal Inform. dan Komputer), vol. 1, no. 1, hal. 1-7, 2016, doi: 10.26798/jiko.2016.v1i1.15.

[32] M. L. Sestiayunda dan F. P. H, "Pengembangan Sistem Informasi Booking Service Motor Honda Pada Pt. Pacific Motor Ii Bekasi Berbasis Web," J. Inkofar, vol. 41, no. 2, hal. 84-93, 2017.

[33] M. Sobri dan Suyanto, “APLIKASI PENGOLAHAN DATA ADMINISTRASI BERBASIS WEB STUDI KASUS SEKOLAH DASAR NEGERI 16 KAYUAGUNG," hal. 37-42, 2016.

[34] C. A. Sugianto dan I. Aulia, "Pengembangan Sistem Informasi Kerjasama Berbasis Web Studi Kasus: Pada SEAMOLEC," J. RESTI (Rekayasa Sist. dan Teknol. Informasi), vol. 1, no. 2, hal. 137, 2017, doi: 10.29207/resti.v1i2.31.

[35] M. Zulkifli, F. Amalia, dan D. Pramono, "Pengembangan Sistem Informasi Akreditasi Borang Standar 3 , Standar 4 , dan Standar 7 berbasis Web ( Studi Kasus: Program Studi Sistem Informasi Fakultas Ilmu Komputer )," vol. 4, no. 1, hal. 232239, 2020.

[36] M. Fiter dan S. Riadi, "Perancangan Sistem Informasi UKM Kotim Berbasis Web Dan Android," $J$. Penelit. Dosen Fikom, vol. 10, no. 2, 2019.

[37] S. L. Hanifa, "Pengambangan Sistem Informasi Pendaftaran Lowongan Pekerjaan Berbasis Web untuk Bursa Kerja Khusus (BKK) di Sekolah Menengah Kejuruan (SMK) Tulungagung," JIPI (Jurnal Ilm. Penelit. dan Pembelajaran Inform., vol. 05, no. 01, hal. 25-34, 2020.

[38] S. Irawati, N. Santoso, dan R. A. Siregar, "Pengembangan Sistem Informasi Perawatan Luka di Praktik Mandiri Pedis Care Malang berbasis
Web," J. Pengemb. Teknol. Inf. dan Ilmu Komput., vol. 3, no. 11, hal. 10855-10864, 2019.

[39] A. M. Munir dan S. R. Cholil, "SISTEM INFORMASI PENUNJANG KOMPETENSI LULUSAN (SIPKOL) BERBASIS WEB MENGGUNAKAN FRAMEWORK CODEIGNITER DI FAKULTAS TEKNOLOGI INFORMASI DAN KOMUNIKASI UNIVERSITAS SEMARANG," Pengemb. Rekayasa dan Teknol., vol. 16, no. 1, hal. 9-16, 2020, doi: 10.1017/CBO9781107415324.004.

[40] M. Safi, P. I. Santosa, dan R. Ferdiana, "Pengembangan Sistem Informasi Sumberdaya Sekolah Kota Ternate Berbasis Web Dengan Metode Rapid Application," J. POSITIF, vol. I, no. 2, hal. 33-42, 2016.

[41] T. Sriwahyuni, O. Oktoria, dan I. P. Dewi, "Pengembangan Sistem Informasi Manajemen Pariwisata Berbasis Web," J. Pengemb. Teknol. Inf. dan Ilmu Komput., vol. 3, no. 10, hal. 10366-10272, 2019, doi: 10.24036/tip.v12i1.184.

[42] M. A. Arsul, Y. T. Mursityo, dan A. D. Herlambang, "Pengembangan Sistem Informasi Manajemen Indekos Berbasis Web Dengan Menggunakan Metode Pengembangan Rational Unified Process (RUP)," J. Pengemb. Teknol. Inf. dan Ilmu Komput., vol. 3, no. 6, hal. 5953-5961, 2019.

[43] W. P. David Josua Hutahaean, Niken Hendrakusma Wardani, "Pengembangan Sistem Informasi Penyewaan Gedung Berbasis Web dengan Metode Rational Unified Process (RUP) (Studi Kasus: Wisma Rata Medan)," J. Pengemb. Teknol. Inf. dan Ilmu Komput., vol. 3, no. Vol. 3, No. 6, Juni, hal. 5789-5798, 2019.

[44] O. Komarudin dan D. Kurniadi, "PERANCANGAN SISTEM PELAYANAN INFOMASI WARGA 


BINAAN PEMASYARAKATAN
RUMAH TAHANAN NEGARA
GARUT BERBASIS WEB DAN
SHORT MESSAGE SERVICE
GATEWAY," J. Algoritm. Sekol.
Tinggi Teknol. Garut, vol. 14, no. 2,
hal. 240-245, 2017, doi:
10.1017/CBO9781107415324.004.

[45] N. Novianti dan R. Setiawan, "Pengembangan Sistem Informasi Jasa Menjahit Berbasis Web Pada Ganesha Tailor Garut," J. Algoritm., vol. 13, no. 2, hal. 246-253, 2017, doi: 10.33364/algoritma/v.13-2.246.

[46] H. Rafidi, S. A. Wicaksono, dan W. Purnomo, "Pengembangan Sistem Informasi Pengajuan Perbaikan Sarana Prasarana Teknologi Informasi Berbasis Web Studi Kasus Pada RSUD Dr . Saiful Anwar Kota Malang," vol. 3, no. 3, hal. 30533060, 2019.

[47] T. Sugiharto dan M. Irwansyah, "Inovasi Pengembangan Sistem Informasi Pengelolaan Surat Keterangan Pendamping Ijazah Berbasis Web," J. Media Inform. Budidarma, vol. 4, no. 2, hal. 325331, 2020, doi: 10.30865/mib.v4i2.1903.

[48] A. Amborowati dan R. Marco, "PERANCANGAN SISTEM INFORMASI PENDAFTARAN MAHASISWA AKTIF KEMBALI DI STMIK AMIKOM YOGYAKARTA," J. Ilm. Data Manaj. dan Teknol. Inf., vol. 17, no. 2, 2016.

[49] R. Irmayani Rahmat dan P. Wibowo Yunanto, "Perancangan Dan Pengembangan Aplikasi Sistem Informasi Monitoring Perkuliahan Dan Kehadiran Mahasiswa Berbasis Web," PINTER J. Pendidik. Tek. Inform. dan Komput., vol. 1, no. 1, hal. 39-50, 2017, doi: http://doi.org/10.21009/pinter.1.1.6. [50] Marijan dan S. Nurajizah,
"Perancangan Sistem Informasi Akademik Berbasis Web Pada Sd Islam Luqmanul Hakim Bekasi Pendahuluan," JURTEKSI (Jurnal Teknol. dan Sist. Informasi), vol. VI, no. 1, hal. 71-78, 2019, doi: https://doi.org/10.33330/jurteksi.v6i1. 399.

[51] B. I. Purnama, "PERANCANGAN SISTEM INFORMASI TOKO BERBASIS WEB PADA PT INDOMARCO PRISMATAMA JAKARTA," vol. 12, no. 1, hal. 6176, 2020, doi: https://doi.org/10.29103/techsi.v12i1. 2318.

[52] R. I. Anugrah, "Pengembangan Sistem Informasi Penjadwalan Mata Kuliah Berbasis Web Di Fakultas Teknik Universitas Negeri Makassar," $J$. Pendidik., vol. 6, no. 2, 2018.

[53] A. Megawati dan D. Gustina, "Membangun Sistem Informasi Monitoring Kegiatan Proyek Pemancar Sinyal BTS Berbasis Web Pada PT . Swatama Mega Teknik," J. Ilm. FIFO, vol. X, no. 1, hal. 22-28, 2018.

[54] D. S. Budi, T. A. Y. Siswa, dan H. Abijono, "Analisis Pemilihan Penerapan Proyek Metodologi Pengembangan Rekayasa Perangkat Lunak," TEKNIKA, vol. 5, no. 1, hal. 24-31, 2016.

[55] W. W. Widiyanto, “ANALISA METODOLOGI PENGEMBANGAN SISTEM DENGAN PERBANDINGAN MODEL PERANGKAT LUNAK SISTEM INFORMASI KEPEGAWAIAN MENGGUNAKAN WATERFALL DEVELOPMENT MODEL, MODEL PROTOTYPE, DAN MODEL RAPID APPLICATION DEVELOPMENT (RAD)," J. Inf. Politek. Indonusa Surakarta, vol. 4, no. 1, hal. 34-40, 2018.

[56] I. F. M. Rachmat, "IMPLEMENTASI 
METODE RATIONAL UNIFIED PROCESS PADA PERANCANGAN APLIKASI PEMBAGIAN HARTA WARISAN BERBASIS ANDROID," J. IPSIKOM, vol. 5, no. 2, 2017.

[57] D. Jayanti, S. Komariah, dan Akmal, "Eksistensi Penelitian Pengembangan R\&D." [Daring]. Tersedia pada: https://www.academia.edu/37670441/ Eksistensi_Penelitian_Pengembangan _R_n_D_.docx.

[58] Dr.R.Kamatchi, P. J. Iyer, dan P. S. Singh, "Software Engineering:Web Development Life Cycle," Int. J. Eng. Res. Technol., vol. 2, no. 3, hal. 1-4,
2013.

[59] Y. Pradifta, Terttiaavini, dan Suryati, "SISTEM INFOMASI SELEKSI BERKAS LAMARAN CALON GURU SECARA ONLINE PADA SMA LTI INDO GLOBAL MANDIRI PALEMBANG," $J$. Inform. Glob., vol. 6, no. 1, hal. 26-31, 2015. 